\title{
Współczesne badania poświęcone I wojnie światowej w Wielkiej Brytanii i Francji - perspektywa kulturoznawcza ${ }^{* * *}$
}

DOI: http://dx.doi.org/10.12775/LC.2018.028

\begin{abstract}
Streszczenie: Artykul jest próbą zarysowania najważniejszych kierunków rozwoju w badaniach poświęconych I wojnie światowej we Francji i w Wielkiej Brytanii w zakresie szeroko pojętego kulturoznawstwa w ciągu ostatnich czterdziestu lat. Autorzy ukazują, jak wczesne badania decyzji militarnych i strategicznych przekształciły się w refleksję o charakterze socjologicznym i kulturowym, poprzez połączenie interpretacji literatury, filmu, sztuki, prasy, pomników, reklam, plakatów, listów czy też praktyk życia codziennego w dobie globalnego kataklizmu. Historia I wojny stała się w ten sposób historią afektów. Autorzy omawiają szereg prac angielsko- i francuskojęzycznych, które poszerzyły rozumienie Wielkiej Wojny o perspektywy przeżyć indywidualnych zarówno żołnierzy, jak i cywilów. Artykuł kończy refleksja na temat nowych horyzontów - postkolonialnych i transkulturowych - w badaniach dotyczących I wojny światowej.
\end{abstract}

Słowa kluczowe: I wojna, nauki historyczne, kulturoznawstwo, literaturoznawstwo, cielesność, trauma, cierpienie, płeć kulturowa, postkolonializm, komparatystyka

* Profesor nadzwyczajny w Katedrze Filologii Angielskiej Uniwersytetu Mikołaja Kopernika w Toruniu. Jej zainteresowania badawcze obejmują: literackie obrazy wojny, literaturę postkolonialną oraz komparatystykę. E-mail: kallas@umk.pl.

** Dr hab., adiunkt w Katedrze Filologii Romańskiej Uniwersytetu Mikołaja Kopernika w Toruniu. Jego badania koncentrują się na współczesnych literaturach francuskojęzycznych. E-mail: piotr.sadkowski@umk.pl.

*** Artykuł ten jest oparty na intensywnych lekturach autorów podczas pracy nad projektem „Trauma kulturowa I wojny światowej we współczesnej literaturze brytyjskiej, francuskiej i kanadyjskiej", finansowanym ze środków Narodowego Centrum Nauki DEC-2013/11/B/HS2/02871 (kierownik: A. Branach-Kallas, główny wykonawca: P. Sadkowski). 


\title{
First World War Studies in France and Great Britain Today
}

\begin{abstract}
The article is an attempt to trace the most important frameworks in First World War studies in France and Great Britain in the last forty years. The authors show the evolution of militarily and politically focused studies into a cultural analysis centered on literature, film, visual arts, war memorials, press articles, advertisements, posters, letters and everyday rituals practiced during the global cataclysm. The history of the First World War has thus become a narrative of affects. The article discusses a number of important works in English and French that have extended our understanding of the Great War by analyzing the intimate experience of both soldiers and civilians. The authors also signal new - postcolonial and transcultural - frameworks that will potentially transform First World War studies in the future.
\end{abstract}

Keywords: First World War studies, history, culture, literature, body, trauma, grief, gender, postcolonial studies, transcultural studies

elem artykułu jest próba zarysowania istotnych kierunków rozwoju w badaniach poświęconych I wojnie światowej we Francji i w Wielkiej Brytanii w ciągu ostatnich czterdziestu lat. Zainteresowanie pierwszym globalnym konfliktem XX wieku zdecydowanie wzrosło pod koniec ubiegłego stulecia. W setną rocznicę I wojny światowej można zaobserwować swoistą eksplozję badań nad konfliktem lat 1914-1918. Oprócz niezliczonych publikacji na ten temat w Wielkiej Brytanii oraz - w mniejszym zakresie - we Francji, są organizowane liczne wystawy, konferencje, debaty, wydarzenia upamiętniające hekatombę sprzed stu lat. Podczas gdy w drugiej połowie XX wieku tematyka II wojny światowej dominowała w kręgach akademickich (Winter and Prost 2005: 1), w latach 2014-2018, szczególnie w świecie anglosaskim, to I wojna stała się tematem wiodącym. Badania na temat konfliktu lat 1914-1918 poszerzają się ciągle o nowe pola badawcze i generują nowe perspektywy analityczne. Same granice czasowe wojny są przedstawiane w bardzo różny sposób: z perspektywy francuskiej punktem wyjścia jest wojna pruska tocząca się od lipca 1870 do stycznia 1871 roku$^{1}$ oraz kult zemsty (Clark 2017: 148), który rozwiną się we Francji po aneksji Alzacji i Lotaryngii przez Niemców. Wizja badaczy niemieckich obejmuje swoim zasięgiem lata 1914-1945, łącząc obie wojny globalne w jedną całość. Dla Rosjan czy Amerykanów to rok 1917 jest punktem zwrotnym w historii (Winter and Prost 2005: 197). Pierwsza wojna światowa nie jest więc faktem historycznym o jasno określonych granicach, lecz zjawiskiem natury konceptualnej, egzystencjalnej i wyobrażeniowej (ibid.: 6). W dzisiejszym świecie zaawansowanych technologii i względnego bezpieczeństwa trudno zrozumieć, jak ludzie początku wieku mogli stawić czoła tak ekstremalnym wydarzeniom.

\footnotetext{
1 Na temat relacji między I wojną światową a konfliktem francusko-pruskim z lat 1870-1871 w kontekście literackim, zob. Schoentjes 2009: 28-32.
} 
Pierwsza wojna jawi się zatem jako ikona katastrofalnego wieku XX (ibid.: 185; Campbell 2005: 261).

W The Great War in History: Debates and Controversies, monografii będącej owocem wieloletniej wspólpracy wybitnych badaczy Amerykanina Jaya Wintera i Francuza Antoine'a Prosta, autorzy zwracają uwagę na trzy modele badań historycznych i kulturoznawczych na temat I wojny światowej. Bezpośrednio po zakończeniu wojny były to głównie badania działań militarnych oraz decyzji politycznych wpływowych dyplomatów i strategów. Podstawowe pytanie, które nurtowało naukowców, dotyczyło kwestii przypisania odpowiedzialności za wybuch wojny jednej ze stron konfliktu. Były to refleksje makro-historyczne, w których perspektywa oddolna, przeżycia wojenne milionów żołnierzy i ich codzienne doświadczenia na froncie nie stanowily przedmiotu zainteresowania historyków (Winter and Prost 2005: 7). Ten punkt widzenia zaczął wysuwać się na pierwszy plan od lat sześćdziesiątych XX wieku. Historycy zajęli się wówczas badaniem wojny z perspektywy zwykłego żołnierza, nie tylko generałów i dyplomatów. Ponadto dostrzegli ciągłość między pierwszym a drugim globalnym konfliktem. W tej optyce lata 1914-1918 jawią się jako pierwszy etap trzydziestoletniej wojny. Istotne stały się również podobieństwa i różnice pomiędzy konfliktem lat 1914-1918 a jego kontynuacją w latach 1939-1945, a także pomiędzy I wojną a rewolucją październikową (ibid.: 15-22). Od lat osiemdziesiątych XX wieku badaczy zaczęła natomiast interesować przede wszystkim kultura i tożsamość jednostek uwikłanych w konflikt wojenny (ibid.: 25-27). Rozwój studiów kulturoznawczych, feministycznych, postkolonialnych, kultura postmodernistyczna i jej fascynacja białymi plamami historii oraz doświadczeniem Innego, rozkwit badań nad pamięcią i traumą - oto czynniki, które w dużej mierze przyczyniły się do zmiany perspektywy badawczej w omawianej dziedzinie. Badania na temat I wojny wkroczyły również w znacznie bardziej dynamiczną fazę dzięki pojawieniu się takich autorytetów, jak autorzy wspomnianej publikacji, Jay Winter i Antoine Prost, oraz całego zespołu badawczego współpracującego ze Stéphane’em Audoinem-Rouzeau, Jeanem-Jakiem Beckerem oraz Annette Becker.

Winter i Prost przywołują trzy daty istotne na poszczególnych etapach badań. W 1935 roku nastąpiła pierwsza publiczna debata francuskich i niemieckich historyków zajmujących się konfliktem lat 1914-1918. Dla tego pokolenia wojna stanowiła przede wszystkim wydarzenie polityczne, bliski był im punkt widzenia pruskiego generała Carla Gottfrieda von Clausewitza, przedstawiony w klasycznym dziele $O$ wojnie (1832). Pierwszą wojnę postrzegano jako konflikt zwaśnionych narodów; stanowiła ona kulminację procesów zapoczątkowanych w XIX wieku. Dla drugiego pokolenia badaczy symbolicznym punktem była pięćdziesiąta rocznica I wojny. Na ich rozważania ogromny wpływ miały realia świata podzielonego przez żelazną kurtynę. Pojmowali oni wydarzenia lat 1914-1918 jako tragedię, w którą uwikłane były różne grupy społeczne: żołnierze, robotnicy, cywile. Konflikt społeczny stał się ważniejszą płaszczyzną analityczną niż ten międzynarodowy. W trzecim etapie natomiast punktem zwrotnym był rok 1992, kiedy to otwarto we francuskim miasteczku Péronne nad Sommą L'Historial de la Grande Guerre - muzeum Wielkiej Wojny trzech narodów: francuskiego, brytyjskiego i niemieckiego. Przemoc, barbarzyństwo, zagłada to ważne aspekty tych badań, a państwo czy też struktury społeczne schodzą na dalszy plan. Procesy mikro-historyczne, przeżycia jednostkowe stają się natomiast kluczem do zrozumienia wydarzeń historycznych w makroskali. Co istotne, jest to moment, kiedy narracja na temat I wojny staje się historią afektów (ibid.: 201-210). Literatura 
piękna, sztuka, prasa, plakaty, listy, pocztówki, reklamy, życie codzienne, a także swoista archeologia Wielkiej Wojny, skupiona na analizie przedmiotów związanych z konfliktem (Saunders 2005: 160) - oto nowy materiał badawczy, odsłaniający nieznane dotąd perspektywy. W ten sposób na przełomie XX i XXI wieku badania historyków, kulturoznawców i literaturoznawców zaczynają się zazębiać.

Kultura wojny (culture de guerre) to termin szczególnie popularny wśród naukowców francuskich, który pozwala zrozumieć, w jaki sposób narody europejskie oraz podległe im kolonie mogły zaangażować się tak entuzjastycznie w konflikt wykorzystujący śmiercionośne technologie. Kultura wojny nie była jedynie skutkiem konfliktów, lecz także ich zarzewiem, owocem oddziaływania czynników militarnych, ekonomicznych, społecznych, propagandowych, a także zjawiskiem, które umożliwiło brutalną rzeź najbardziej cywilizowanych narodów Europy na początku XX wieku (Becker et al. 1994: 7-9; Winter and Prost 2005: 164). Często przywoływany w kontekście francuskim termin „brutalizacji mentalności” tłumaczy przemiany światopoglądowe i etyczne, które sprawiły, iż Alianci uwierzyli w hiperboliczny obraz demonicznych Hunów wyruszających na podbój Europy, zdeprawowanej rasy, którą należało jak najszybciej wyeliminować (Winter and Prost 2005: 7-10). Niemcy mieli stanowić antytezę cywilizacji: tzw. pruska mentalność, despotyzm, militaryzm, bezwzględność i okrucieństwo - oto jak przedstawiano cechy narodu niemieckiego. W tej perspektywie Aliantów wyobrażano sobie jako obrońców cywilizacji, chrześcijaństwa i podstawowych wartości międzyludzkich (Vance 1997: 22). Nastąpił masowy powrót do religii, a uczucia metafizyczne wpłynęły w dużej mierze na eskalację emocji w kulturze wojny (Winter and Prost 2005: 164).

We Francji współczesne badania z zakresu historii kulturowej uwidaczniają istotną rolę czynnika religijnego w odniesieniu do postaw indywidualnych wobec Wielkiej Wojny i ich wpływ na relacje, w obszarze polityki, między obozem antyklerykalnym a środowiskami katolickimi. Analizie zostaje poddane zjawisko tzw. religii wojny (religion de guerre) polegające, wśród francuskich katolików, protestantów i żydów, na łączeniu wiary z kultem ojczyzny i w konsekwencji postrzeganiu walki z Niemcami jako „krucjaty” (zob. A. Becker 1994; Audoin-Rouzeau et Becker 2000: 159-185; Fouilloux 2005: 118-119). Emmanuel Godo, interpretując wykorzystywanie wiary w celu legitymizacji wojny jako przejaw kryzysu duchowości europejskiej, zwraca uwagę na analogie w odwoływaniu się do symboli oraz wartości religijnych i cywilizacyjnych w dyskursach propagandowych obu stron konfliktu (Godo 2016). W dziedzinie sztuki także, jak zauważa Annette Becker, hasła zaczerpnięte $\mathrm{z}$ dyskursu religijnego, takie jak: „mesjanizm, nadzieja, rozpacz, apokalipsa, odkupienie, cierpienie, ofiara, krucjata, kara”, inspirowały rozmaite działania artystyczne związane zarówno z kulturą masową, dewocyjną (w praktykach symbolicznych upamiętniania poległych), jak i z propagandą, a także z twórczością awangardową ${ }^{2}$.

Emocje zwykłych ludzi, którzy przetrwali kataklizm lat 1914-1918 stały się również kluczem do zrozumienia zbiorowych nastrojów w trakcie konfliktu i po wojnie. Wśród najważniejszych publikacji na ten temat warto omówić książkę Jaya Wintera z 1995 roku Sites of Mourning, Sites of Memory: The Great War in European Cultural History, w której autor

2 Francuska badaczka wyróżnia tu cztery motywy zaczerpnięte z tradycji chrześcijańskiej: rzeź niewiniątek, Apokalipsę według Świętego Jana, mękę i zmartwychwstanie Chrystusa, boleść Matki Bożej. Wśród praktyk awangardowych Becker zwraca uwagę m.in. na reinterpretacje średniowiecznego tematu tańca śmierci (danse macabre) np. w twórczości Otto Friesza, Otto Dixa i innych artystów po obu stronach frontu (A. Becker 2005). 
analizuje „kult żałoby”, jaki rozwinął się w krajach europejskich, a przede wszystkim we Francji, w Wielkiej Brytanii i Niemczech po roku 1918. Zwraca uwagę na kontrast między popularną wśród elit ironiczną, abstrakcyjną symboliką modernistyczną, a bardziej tradycyjną retoryką upamiętniania, pomagającą tym, którzy utracili swoich bliskich, pogodzić się z przeżytą tragedią. Winter nie neguje korelacji pomiędzy modernizmem a I wojną, lecz zaznacza, iż kult poległych w Europie w latach powojennych wykorzystywał bardziej konwencjonalne środki artystyczne (Winter 1996: 3-5). Badacz omawia również różne metody, jakie wykorzystywali pogrążeni w żałobie Europejczycy, aby ukoić ból po utracie najbliższych, takie jak kontakt z duchami zmarłych za pośrednictwem medium (ibid.: 54-77) czy też powstanie swoistych „wspólnot żałoby” wśród ludzi, których nie łączyły więzi rodzinne, lecz którzy ze względu na przeżytą traumę wojenną potrafili wspierać się wzajemnie, zarówno w sensie emocjonalnym, jak i ekonomicznym (ibid.: 29-53). Wskazuje również na rolę pielgrzymek na pola bitew oraz cmentarze wojenne, a także na funkcję niezliczonych pomników ku czci zmarlych, budowanych wówczas w całej Europie. Winter zauważa, iż w latach powojennych akt dotykania pomników ku czci poległych i wyrzeźbionych na nich nazwisk stanowił ważny element w rytuale żałoby (ibid.: 113-115). Podkreśla, że budowa pomników narodowych służyła również celom politycznym. Oprócz stabilizacji zarówno młodych, jak i starych narodów w latach powojennych, pomniki te dawały wyraz przeświadczeniu, iż śmierć milionów żołnierzy miała doniosłe znaczenie - ofiary poniesione w czasie wojny miały moc odkupienia, a na ich zgliszczach miał powstać nowy, lepszy świat. Co istotne, w swym studium pamięci, rozpaczy i żałoby Winter łączy interpretacje literatury, filmu i sztuki z analizą praktyk religijnych, pomników, zjawisk społecznych, jednostkowych opowieści rodzinnych, próbując w ten sposób stworzyć pełną historię afektów $\mathrm{w}$ dobie globalnego kataklizmu.

W badaniach nad wymiarem antropologicznym i kulturowym Wielkiej Wojny we Francji szczególne miejsce zajmuje opublikowana w 2000 roku praca Stéphane’a AudoinaRouzeau i Annette Becker 14-18, retrouver la Guerre. Cechą wspólną publikacji francuskich badaczy i Sites of Mourning Jaya Wintera jest swoisty humanizm naukowy polegający na połączeniu podejścia historiograficzno-socjologicznego z postawą empatyczną autorów, dla których nadrzędnym celem jest z ro zu mi e n i e koszmaru Wielkiej Wojny nie tyle jako konfliktu militarnego politycznych mocarstw, ale jako ludzkiego c i e r p i e n ia. Faktograficzna rekonstrukcja przeszłości stanowi więc punkt wyjścia do interpretacji, w perspektywie antropologicznej, wplywu wojny na rozmaite sfery życia jednostek i społeczeństwa oraz jej konsekwencji dla następnych pokoleń. Książka obejmuje trzy obszary problemów, nazwane kolejno: Przemoc, Krucjata i Żałoba. Badacze pochylają się nad zjawiskiem przemocy w kontekście operacji wojskowych oraz nad problemem cierpień, które są udziałem jeńców wojennych i ludności cywilnej. Istotną część pracy zajmuje także analiza czynników ideologicznych, propagandowych, kulturowych i religijnych kształtujących postawy ludzkie wobec wojny. Skupiając się na zjawisku żałoby, traktowanej w dwóch wymiarach - zbiorowym i jednostkowym, Annette Becker i Stéphane Audoin-Rouzeau podkreślają, iż skala strat ludzkich (tzn. liczba Francuzów poległych, rannych i/lub straumatyzowanych) pozwala stwierdzić, że prawdopodobnie całe społeczeństwo francuskie zostało w różny sposób naznaczone cierpieniem (Becker et Audoin-Rouzeau 2000: 81), co w konsekwencji spowodowało niemożność zaleczenia traumy. Według Audoina-Rouzeau i Becker, odwołujących się do wprowadzonego przez Jaya Wintera, wspomnianego wyżej 
pojęcia „wspólnot żałoby”, aby wypełnić brak w dotychczasowych badaniach nad spustoszeniem spowodowanym przez I wojnę należy podjąć starania, by odtworzyć losy osób, które utraciły bliskich (tzn. żon, dzieci, rodziców, narzeczonych, dziadków, bliższych i dalszych krewnych, przyjaciół czy znajomych poległych) w skali mikro-historycznej i w ten sposób uchwycić relację między żałobą zbiorową a intymnym wymiarem straty (ibid.: 239-243).

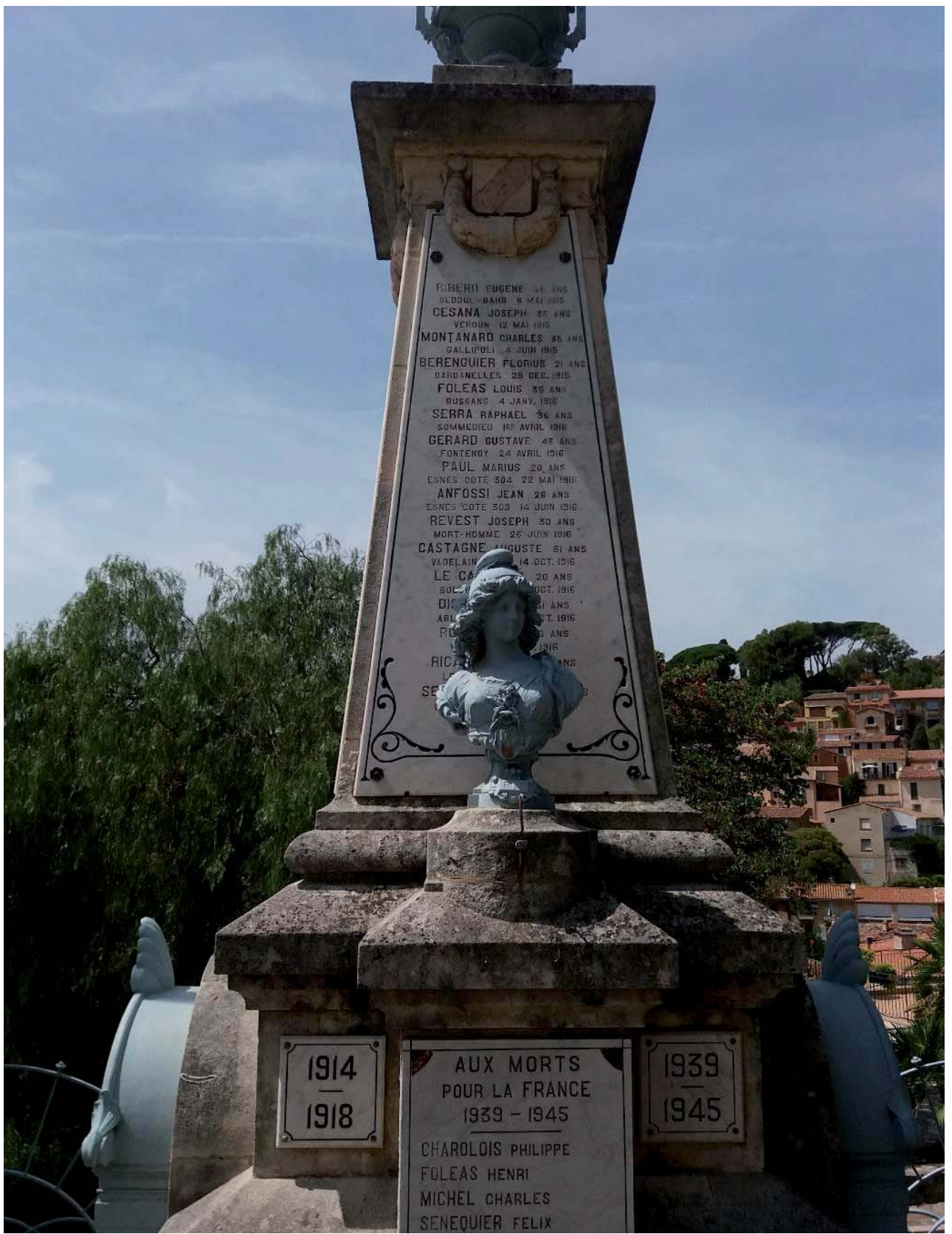

Pomnik ku czci poległych żołnierzyw Bornes-Les-Mimosas na Lazurowym Wybrzeżu Fot. A. Branach-Kallas 
Zwrot ku intymnym przeżyciom jednostki zaowocował również rozwojem badań, które koncentrują się na osobistych doznaniach żołnierzy bardziej niż na działaniach militarnych strategów i polityków. W tej perspektywie wojna toczy się w umysłach szeregowców i oficerów. Podczas gdy psychiatria wojskowa była przez dłuższy czas zaniedbaną dziedziną nauki, badania prowadzone po wojnie w Wietnamie oraz rozwój teorii feministycznych, w tym prac nad histerią jako konstruktem kulturowym, zwróciły uwagę badaczy na zjawisko szoku artyleryjskiego w czasie I wojny światowej ${ }^{3}$. Podjęto zatem próby odtworzenia historii medycznej shell shock i spojrzenia przez jego pryzmat na procesy psychologiczne i obyczajowe w trakcie i po zakończeniu konfliktu. Skala urazów psychicznych w latach 1914-1918 zaskoczyła personel medyczny oraz dowódców wojskowych i wywołała swoisty kryzys poznawczy i etyczny. Mężczyźni wykazujący objawy podobne do histerii, uznawanej tradycyjnie za dolegliwość kobiecą, podważali bowiem wiktoriański ideał męskości, obowiązujący przede wszystkim w klasach wyższych, definiowany jako połączenie opanowania emocjonalnego, odwagi i poczucia honoru. „Histeryków” poddawano zatem ciężkim karom, a metody leczenia były często niehumanitarne, szczególnie w Niemczech i we Francji. Długotrwałe skutki urazów utrudniały reintegrację weteranów w rzeczywistości powojennej ${ }^{4}$. Żołnierz cierpiący na shell shock stał się symbolem okaleczonego przez wojnę społeczeństwa, szczególnie popularnym w świecie anglojęzycznym (Winter 2014b: 328).

Pracą, która zasadniczo zmieniła rozumienie krajobrazów emocjonalnych I wojny, było opublikowane w 1979 roku dzieło Erica J. Leeda No Man's Land: Combat and Identity in World War I. Punktem wyjścia autora jest założenie, iż udział w wojnie łączył się z głęboką przemianą ideologiczną i psychiczną żołnierzy. W sierpniu 1914 roku zarówno w Niemczech, jak i w krajach alianckich wojna jawiła się jako szansa odbudowy poczucia wspólnoty. Miała ona obalić różnice klasowe i załagodzić konflikty społeczne (Leed 1979: 39-72). Armia stanowiła kwintesencję tak pojętej wspólnoty, gdyż gromadziła żołnierzy różnego pochodzenia społecznego wspólnie walczących o ten sam cel (ibid.: 56). Żołnierz zatem wyrzekał się dobrowolnie swej jednostkowej tożsamości, stając się częścią zbiorowości, będącej na usługach narodu, czego symbolem był mundur (ibid.: 205). Realia wojny podważyły te idealistyczne założenia - w okopach żołnierze pojęli bowiem, iż przyczyną wojny nie jest konflikt idei, a są nią interesy materialne klas wyższych. Przeżycia frontowe ukazujące bezgraniczne okrucieństwo ludzkie sprawiły, że świat tradycyjnych wartości stawał się dla żołnierzy coraz mniej rzeczywisty (ibid.: 23). W ich doświadczeniu wojna była ciężką, żmudną pracą i w tym sensie stanowiła kwintesencję kapitalizmu. Leed definiuje więc I wojnę jako intymne doświadczenie nowoczesności rzeszy powołanych do wojska mężczyzn (ibid.: 193). Konflikt ten zaostrzył także podziały społeczne, gdyż wzbogaciło się na nim wielu cywili, podczas gdy w rzeczywistości powojennej często pozostawieni bez wsparcia państwa weterani - uznani za zdziczałych barbarzyńców, a nie bohaterów - zostali pozbawieni godności jako mężczyźni i istoty ludzkie (ibid.: 196). Ważnym aspektem dzieła Leeda jest również zarys historii traumy wojennej i sposobów jej leczenia podczas I wojny światowej.

3 Trauma I wojny stanowi ważny temat wśród badaczy anglosaskich. W innych kręgach kulturowych nie jest to wiodący temat badawczy (Winter and Prost 2005: 185).

${ }^{4} \mathrm{Na}$ temat zjawiska shell shock w ujęciu transkulturowym, zob. Shephard 2002: 18-23; Lerner 2005; Winter 2014b. 
Ostatnie dekady poszerzyły zakres prac nad ewolucją pojęcia męskości podczas wojny i po jej zakończeniu. Głęboką transformację mężczyzn w okopach poprzez pryzmat ich cielesności omawia Joanna Bourke w Dismembering the Male: Men's Bodies, Britain and the Great War (1999). Zdaniem badaczki I wojna doprowadziła do swoistego kryzysu cielesności - od mężczyzn oczekiwano cierpliwego znoszenia bólu i cierpienia, lecz zmasakrowane ciała były głębokim szokiem dla nich samych i cywilów (Bourke 1999: 251). Unicestwione zwłoki żołnierzy, które nie doczekały się pochówku, znacząco wpłynęły na zmianę norm obyczajowych dotyczących rytuałów pośmiertnych (ibid.: 210-235; Cannadine 1981: 187-242). Bourke analizuje, jak społeczeństwo angielskie postrzegało kalekich żołnierzy i jakie opracowało metody ich reintegracji. Ilustruje również zmieniające się relacje między żołnierzami, którzy w ekstremalnych warunkach na froncie okazywali sobie troskę i serdeczność wykraczającą poza obowiązujące normy męskości. Podkreśla jednak, iż te homospołeczne zachowania nie przetrwały rzeczywistości wojennej, powracający z wojny mężczyźni pragnęli bowiem odzyskać utraconą pozycję w rodzinie (Bourke 1999: 124-170). Kryzys cielesny zarysowany przez Bourke zmienił jednak percepcję męskiego ciała, które zaczęto postrzegać jako bardziej kruche. Lata spędzone w okopach sprawily ponadto, że męskość, doświadczona na poziomie cielesności, stała się czynnikiem jednoczącym brytyjskich żołnierzy wbrew różnicom wieku, klasy, wykształcenia (ibid.: 251).

Badania nad tożsamością żołnierzy zwróciły również uwagę naukowców na kształtowanie się pojęcia płci kulturowej w trakcie I wojny, a zatem i podmiotowości kobiecej. Przemiany, które zaszły w życiu kobiet w latach 1914-1918, stały się ważnym obszarem badawczym we Francji i w krajach angielskojęzycznych od lat osiemdziesiątych XX wie$\mathrm{ku}^{5}$. Wkrótce obalono popularną tezę, iż wojna doprowadziła do wyzwolenia kobiet, które przejęły władzę od mężczyzn ${ }^{6}$. W istocie pod nieobecność mężczyzn kobiety we Francji i w krajach angielskojęzycznych zachęcano do przejęcia ich obowiązków zawodowych, lecz jednocześnie zaznaczano, że jest to poświęcenie, którego się od nich oczekuje jedynie do czasu powrotu żołnierzy z frontu. Ponadto, tradycyjne role płciowe odgrywały olbrzymią rolę $\mathrm{w}$ tym szczególnie chaotycznym okresie: kobiety miały być strażniczkami ogniska domowego, a ich wzorowa postawa moralna pod nieobecność ojców, mężów i braci miała przyczynić się do zwycięstwa Aliantów. Podkreślano tradycyjną rolę kobiet jako matek: ich zadaniem było przede wszystkim wydawanie na świat i wychowywanie dzieci. Obowiązek ten był szczególnie agresywnie promowany przez francuską propagandę, ponieważ obawiano się, iż spadek rozrodczości Francuzek, w porównaniu z Niemkami, doprowadzi do niedoboru żołnierzy i przechyli szalę zwycięstwa na rzecz Niemców (Grayzel 1999: 104-105). To w latach 1914-1918 wszedł w użycie angielski termin home front - front domowy, definiowany jako dychotomia frontu militarnego, a w hasłach lansowanych przez propagandę zamieszkany wyłącznie przez kobiety (ibid.: 11). W istocie granice między obydwoma frontami nie były szczelne: kobiety znajdowały się pod obstrzałem artyleryjskim w Paryżu (ibid.: 48), przebywały w strefie wojennej na terytoriach okupowanych na północy Francji

\footnotetext{
${ }^{5}$ Wśród przełomowych publikacji na ten temat warto wymienić: Thébaud 1986; Ouditt 1994; Grayzel 1999. Zob. również wywiad z F. Thébaud w tym tomie.

6 Tezę tę wysunęła Sandra Gilbert (1983). Kobiety uzyskały wprawdzie prawa wyborcze w Wielkiej Brytanii po I wojnie światowej, podczas gdy we Francji nastąpiło to dopiero w roku 1944, nie miało to jednak większego przełożenia na ich życie codzienne. Wojna wpłynęła jedynie na polepszenie się sytuacji wykształconych kobiet klasy średniej (zob. Grayzel 1999: 190-225; Thébaud 1986: 291).
} 
(A. Becker 2004: 151-171) oraz jako pielęgniarki na froncie zachodnim czy na statkach szpitalnych w Azji i na Bliskim Wschodzie (Ouditt 1994: 7-46; Hallet 2014). Pomimo tego, ich obecność była jednak przez lata pomijana. Dziś uważa się, że wojna totalna wymaga całościowego spojrzenia na społeczeństwo, dlatego działania militarne nie powinny być analizowane $\mathrm{w}$ oderwaniu od procesów zachodzących w tym samym czasie poza frontem (Winter and Prost 2005: 172). Zwrot w badaniach poświęconych I wojnie doprowadził również do publikacji antologii i opracowań krytycznych na temat nieznanej dotąd szerszej publiczności powstałej w latach 1914-1918 i w okresie międzywojennym literatury pięknej autorstwa kobiet.

Eksplozja badań nad pamięcią w ostatnich dekadach uświadomiła również badaczom rolę mechanizmów upamiętniania, które wpływają na sposób, w jaki myślimy o wojnie. Wśród licznych wyobrażeń o I wojnie niektóre zyskały swoisty status metanarracji. Jest to szczególnie widoczne w kontekście brytyjskim. Podczas gdy we Francji, mimo licznych głosów kontestacyjnych, I wojnę zapamiętano głównie jako okupione głębokim poświęceniem zwycięstwo ${ }^{7}$, w Wielkiej Brytanii powszechna stała się narracja porażki (Hynes 1990: 439-469; Todman 2005). W tym kontekście emblematyczną postacią jest dotknięty głęboką traumą brytyjski oficer na froncie zachodnim, który utracił wszelkie złudzenia co do szlachetnych celów konfliktu. Ważny element mitu to obraz lwów prowadzonych przez osły, podkreślający nieodpowiedzialność generalicji, której nieprzemyślane decyzje doprowadziły do śmierci tysięcy żołnierzy. Wyobrażenia o masowej rzezi młodych mężczyzn w okopach frontu zachodniego oddaje również motyw lost generation - straconego pokolenia ${ }^{8}$. Ponadto, $\mathrm{w}$ tej perspektywie I wojna stanowi wielki przełom, wyrwę w dziejach, oddzielającą idealistyczny wiek XIX od świata XX wieku, w którym królują wartości materialne i interesy prywatne. W monografii z 1990 roku A War Imagined: The First World War and English Culture Samuel Hynes zaznacza, że do rozprzestrzenienia tego mitu na temat wojny przyczyniła się przede wszystkim literatura, zwłaszcza zaś poezja stworzona przez poetów-żołnierzy (Hynes 1990: 423-463). Mimo wysiłków historyków podkreślających, iż działania wojenne Brytyjczyków były często strategicznie świetnie przemyślane, uproszczone wyobrażenia o I wojnie jako pozbawionej sensu hekatombie, rozgrywającej się w scenerii krwi, błota, trujących gazów i szczurów grasujących w okopach, utrzymują się w Wielkiej Brytanii do dziś, w świadomości zbiorowej, literaturze, filmie i sztuce (zob. Todman 2008; Wilson 2014).

Kluczową publikacją angielskojęzyczną z pogranicza historii i literaturoznawstwa, dzięki której badania na temat I wojny przyjęly nowy kształt, jest The Great War and Modern Memory Paula Fussella z 1975 roku. Fussell, wybitny historyk amerykański, weteran II wojny światowej jest pierwszym badaczem, który interpretuje I wojnę jako zjawisko o ogromnej sile transformacji społecznej i kulturowej. Twierdzi, że współczesna kultura jest bezpośrednim wytworem I wojny; pewne aspekty nowoczesności - na poziomie języka, światopoglądu, moralności - ukształtowały się w latach 1914-1918 (Fussell 1975: ix). Analizuje dzieła kanonicznych brytyjskich poetów-żołnierzy, takich jak Siegfried Sassoon,

7 Z francuskiego punktu widzenia rzeź I wojny miała głębszy sens, gdyż Francuzi, walczący w niej o prawość, sprawiedliwość i wolność, odnieśli zwycięstwo nad zmilitaryzowaną kulturą niemiecką (Winter and Prost 2005: 195; Prost 1992: 89).

8 Pojęcie straconego pokolenia jest hiperboliczną wizją strat wojennych, popularną wśród wyższych klas społecznych w Wielkiej Brytanii. Tej wizji masowej zagłady całego pokolenia nie potwierdzają dane statystyczne (Cannadine 1981: 232). 
Robert Graves, Wilfred Owen, David Jones, lecz struktura jego pracy jest bardziej tematyczna niż biograficzna'. Rewolucyjnym aspektem The Great War and Modern Memory jest odczytanie wojny jako swoistego tekstu kultury, posługującego się charakterystycznym językiem, symboliką, a przede wszystkim ironią (Campbell 2005: 267-268). Nowatorskie elementy w dziele Fussella to również np. kontrast pomiędzy obrazem sielankowej Anglii a mrocznym światem przemocy i chaosu oraz elementy homoerotyki w relacjach między mężczyznami na froncie ${ }^{10}$. Ta wizja wojny nie była jednak wizją uniwersalną, lecz wytworem wyobraźni angielskiej klasy średniej i wyższej, która przejęła funkcje dowódcze w okopach na froncie zachodnim. Praca Fussella pozornie utrwaliła pewien kanon brytyjskiej poezji pierwszowojennej, który ograniczał się do jednej klasy społecznej. Jego oryginalne interpretacje literatury I wojny zwróciły jednak uwagę licznych badaczy na kwestię płci kulturowej i seksualności oraz pominięte w The Great War and Modern Memory doświadczenia wojenne cywilów i kobiet. Dzieło Fussella stało się fundamentalnym punktem odniesienia w późniejszych badaniach nad konfliktem i przyczyniło się do prób wyjścia poza badania skoncentrowane głównie na działaniach wojennych oraz literackich wizjach wojny poetów-żołnierzy (Campbell 2005: 270-274).

We wspomnianej monografii $A$ War Imagined: The First World War and English Culture Hynes ukazuje korelacje i różnice między literaturą żołnierzy a twórczością powstałą poza frontem w trakcie I wojny światowej. Istotną pracą w tym zakresie jest również Modernism, History and the First World War z 1998 roku, autorstwa Trudi Tate, gdzie oprócz utworów żołnierzy, takich jak Edmund Blunden czy Henri Barbusse, badaczka interpretuje twórczość cywilów. Ważnym aspektem jej analizy jest zwrócenie uwagi na udokumentowaną traumę pośrednią wśród cywilów, objawiającą się natarczywymi fantazjami i niepokojem, których źródłem były wiadomości prasowe $\mathrm{z}$ frontu oraz zdeformowane ciała kalekich weteranów (Tate 1998: 11-16). Taka perspektywa umożliwia Tate zestawienie postaci okaleczonego psychicznie i fizycznie żołnierza z mało znanej powieści Williama Faulknera Soldier's Pay z „wojennymi neurotyczkami” z opowiadań Rudyarda Kiplinga oraz Hildy „H. D.” Doolittle ${ }^{11}$. Badaczka udowadnia w ten sposób, że wojna wywarła głęboki wpływ nie tylko na to, jak żołnierze na froncie postrzegali swą cielesność, lecz również na autopercepcję cywilów, przerażonych takimi wynalazkami, jak moździerze czy czołgi. Konflikt lat 1914-1918 był zatem przeżyciem traumatycznym dla całych społeczeństw, które nie potrafily w pełni zrozumieć rozgrywających się wokół ekstremalnych wydarzeń (ibid.: 1). Niezwykle interesująca w monografii Tate jest również analiza działalności propagandowej Brytyjczyków podczas I wojny światowej i jej wpływu na mistrzów modernizmu, takich jak Ford Madox Ford, David Herbert Lawrence oraz Virginia Woolf. Celem Tate jest przemyślenie relacji między modernizmem a wojną i ujęcie twórczości awangardy modernistycznej

\footnotetext{
9 W odróżnieniu od wcześniejszych ważnych prac, takich jak np. Bergonzi 1965.

10 Na temat homoerotyki i innych zagadnień związanych z seksualnością w tekstach literackich poświęconych Wielkiej Wojnie zob. również Schoentjes 2009: 169-196.

11 Kipling, który zanim stracił na wojnie syna popierał działania wojenne, przedstawia fantazje perwersyjnego wręcz okrucieństwa w wyobraźni cywilów; H. D., amerykańska pisarka i poetka, która mieszkała w Anglii w latach wojennych, urodziła w 1915 roku martwe dziecko, a motyw śmierci nienarodzonego dziecka staje się metaforą zabójczej potęgi wojny w jej twórczości; młodziutki William Faulkner przeszedł szkolenie na pilota, lecz nie zdążył wziąć udziału w wojnie - był więc członkiem sił zbrojnych, lecz nie kombatantem, co stało się powodem jego głębokiej frustracji.
} 
jako formy pisarstwa wojennego. Z tego punktu widzenia wojna globalna toczy się w ciałach i umysłach, a także na stronie awangardowych książek - na poziomie języka.

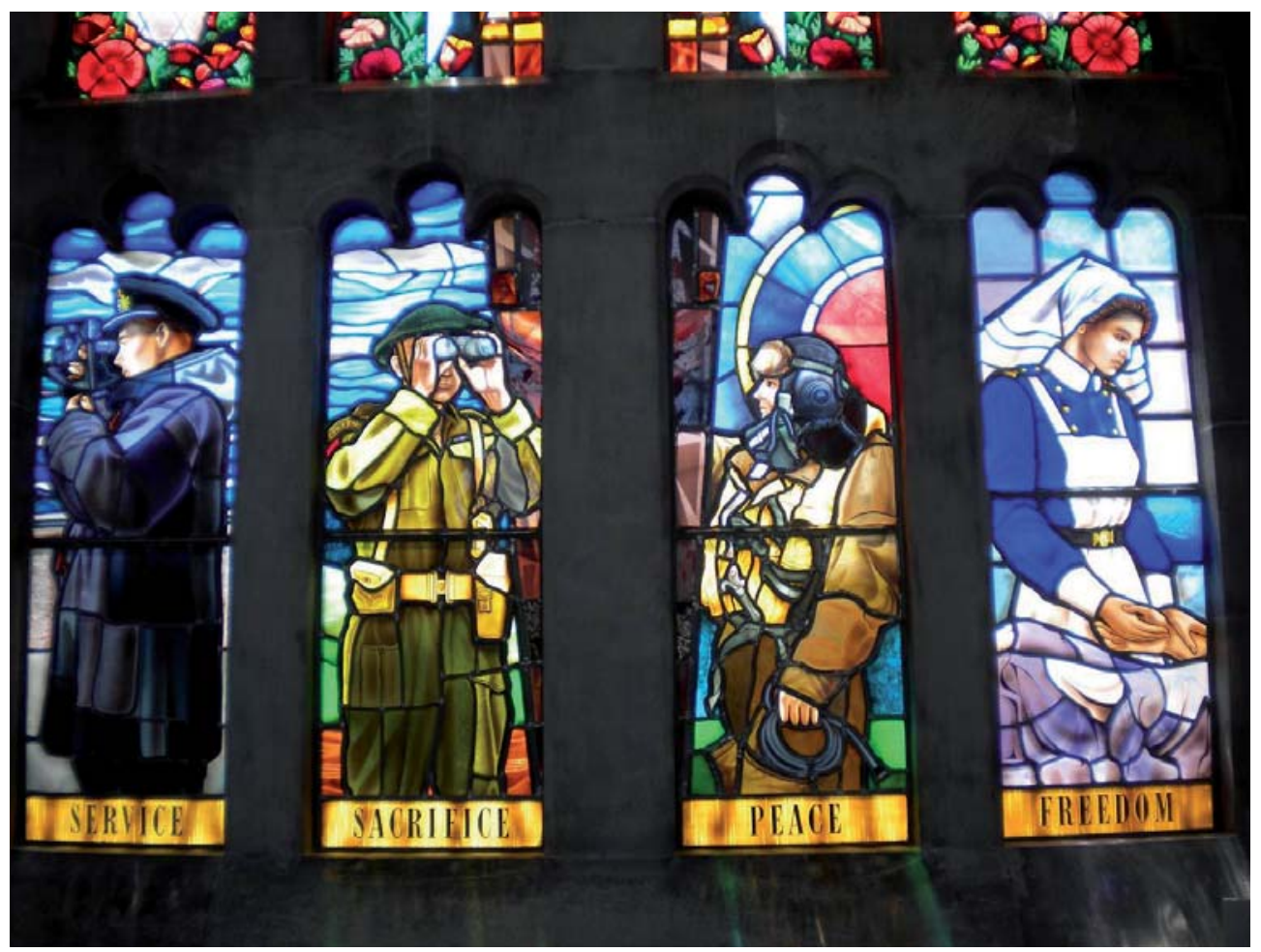

Witraże upamiętniające I wojnę w kaplicy przy Trinity College, University of Toronto

Fot. A. Branach-Kallas

Wyjątkowo oryginalna wydaje się również perspektywa Santanu Dasa w książce z 2005 roku Touch and Intimacy in First World War Literature. Punktem wyjścia Dasa jest swoista ontologia wojny, w której zmysł dotyku określa dominujące doznania żołnierza ${ }^{12}$. Autor przedstawia wnikliwą analizę krajobrazów błota na froncie zachodnim, ujmując tę lepką substancję jako bezkształtną materię unicestwiającą ciała i podmiotowość żołnierzy (Das 2005: 37). Świat błota staje się zatem uniwersum traumy I wojny światowej, która wymyka się werbalizacji. Co ciekawe, Das ukazuje wpływ utworów literackich powstałych w dobie I wojny na konceptualizację pojęcia abiektu, wstrętu, obrzydzenia przez Jean-Paula Sartre’a i Julię Kristevą (ibid.: 49-62). Analizując listy i pamiętniki żołnierzy, badacz przedstawia również szereg rozważań na temat intymnych relacji na froncie, stojących w sprzeczności z homofobicznymi normami kulturowymi określającymi dopuszczalne granice bliskości fizycznej między mężczyznami na początku XX wieku. Szczególnie interesująca jest tu również interpretacja poezji Wilfreda Owena przez pryzmat pobudzonych zmysłów: wojna to wszechobecność błota, agonii, śmierci, rozerwanych na strzępy ciał. Wojna zabija i okalecza, lecz jednocześnie jest źródłem wyjątkowo intensywnych przeżyć - oto pa-

\footnotetext{
12 W odróżnieniu od tezy Davida Trottera, który podkreśla rolę wzroku i węchu w swej analizie literatury pierwszowojennej i przedstawia wojnę w okopach jako źródło edukacji na temat wstrętu (Trotter 2005: 34-56).
} 
radoks doświadczenia poety-żołnierza (ibid.: 172). W Touch and Intimacy in First World War Literature Das przedstawia również inspirującą interpretację wspomnień pielęgniarek, takich jak Vera Brittain, Mary Borden i Irene Rathbone, które służyły jako ochotniczki w szpitalach na froncie. Ratując życie żołnierzy często w trudnych, niebezpiecznych warunkach, kobiety te uczestniczyły w działaniach wojennych i na własny sposób kształtowały przebieg wojny (ibid.: 227). Obcując na co dzień z ciałami rannych mężczyzn, poprzez opatrunki, zastrzyki, masaże, przemywanie ran, tamowanie krwotoków, asystowanie przy amputacjach i innych poważnych zabiegach chirurgicznych, przybierały jednak również rolę świadka pierwszego globalnego konfliktu w jego cielesnym wymiarze. Doznania te stały się źródłem traumy, lecz pielęgniarki musiały ukrywać bolesne przeżycia psychiczne. Ich troska i współczucie były niewspółmierne do nadmiaru otaczającego ich bólu i cierpienia. Rozdarte między aktywną rolą personelu medycznego ratującego ludzkie życie a pasywną rolą świadka „prawdziwych” doświadczeń wojennych, które mogły poznać jedynie pośrednio, pielęgniarki czuły się głęboko wyalienowane, a ich pamiętniki i twórczość literacka oddają ten kryzys emocjonalny na poziomie werbalnym (ibid.: 188-195). Co istotne, w książce Dasa doświadczenia mężczyzn i kobiet na froncie stanowią pewne kontinuum, a niuanse intymnych, cielesnych doświadczeń omówione w poszczególnych rozdziałach pozwalają lepiej zrozumieć wielowymiarową traumę I wojny światowej.

Wymiar cielesny cierpienia i straty spowodowanych przez Wielką Wojnę zajmuje również nadrzędne miejsce w opublikowanej w roku 2001 we Francji pracy Carine Trevisan Les fables du deuil. La Grande Guerre: mort et écriture, łączącej podejście literaturoznawcze z metodami kulturoznawczymi, historycznymi i antropologicznymi stosowanymi przez przywoływanych wcześniej w tym artykule badaczy brytyjskich i francuskich - Jaya Wintera, Antoine’a Prosta, Stéphane’a Audoina-Rouzeau (Trevisan 2001: XVII-XVIII), a także w świetle koncepcji psychoanalitycznych. Jak zapowiada we wstępie książki autorka, celem jej badań była analiza - obejmująca utwory literackie poświęcone I wojnie, opublikowane od roku 1916 do ostatniej dekady XX wieku - narracyjnych strategii kwestionowania społecznych i normatywnych form wyrażania żałoby przez obserwację stosunku podmiotu ludzkiego do ciał ofiar (ibid.: XVI). Literatura jest dla Trevisan wyrazem doświadczania żałoby zarówno przez uczestników i świadków, którzy przeżyli Wielką Wojnę, jak i ich potomków w pierwszym i drugim pokoleniu. Badane teksty stanowią wymowną ilustrację tezy o niemożności zamknięcia pracy żałoby i zabliźnienia traumy, o której pisali Stéphane Audoin-Rouzeau i Annette Becker. Autorka podkreśla, że przeprowadzona analiza literackiego obrazowania traumy I wojny pozwala stwierdzić, iż konflikt z lat 1914-1918 jest dla współczesności „sceną otwierającą”. Dzieje się tak z dwóch powodów. Po pierwsze, Wielka Wojna jest wydarzeniem, które zrodziło „wiek dziedziczący jej niepojmowalne barbarzyństwo". Po drugie, stała się ona, jak pisze autorka, odwołując się do fundamentalnych prac Sigmunda Freuda i Jeana-Bertranda Pontalisa, źródłem refleksji naukowej nad zjawiskiem żałoby (ibid.: 202).

Zainteresowanie perspektywą „Innego” zaowocowało także na przełomie XX i XXI wieku rozwojem badań nad I wojną w krajach postkolonialnych. Warto zwrócić uwagę na to, że w pamięci zbiorowej Australijczyków i Kanadyjczyków, którzy dołączyli do wojny wraz z resztą Imperium Brytyjskiego, I wojna stanowi przełomowy moment, dzięki któremu Australia i Kanada udowodniły swoją niezależność od Wielkiej Brytanii. Bohaterska śmierć 60000 kanadyjskich żołnierzy nie poszła na marne, gdyż stała się zalążkiem niepod- 
ległej Kanady ${ }^{13}$. Podobnie w Australii legenda powstała wokół żołnierzy Anzac (Korpusu Wojskowego Australii i Nowej Zelandii) ukształtowała wizerunek idealnego Australijczyka o cechach narodowych odmiennych od brytyjskich (Seal 2004). Podczas gdy dla białych mieszkańców dominiów podróż na front łączyła się z nostalgicznym powrotem do ojczyzny przodków, którą pragnęli obronić przed germańskim najeźdźcą, dla mieszkańców kolonii brytyjskich i francuskich rasy innej niż biała udział w wojnie był przymusowym podatkiem krwi narzuconym przez odległą metropolię lub podróżą w nieznane do centrum Imperium. W tym sensie I wojnę postrzega się dziś jako strefę kontaktu między Europejczykami a mieszkańcami kolonii. Ostatnie badania wykazują, że armie brytyjska, francuska i amerykańska zmobilizowały podczas I wojny światowej około czterech milionów kolorowych żołnierzy, z których sześćset tysięcy trafiło do Europy (Das 2013: 4). Przeciw tej praktyce protestowali przede wszystkim Niemcy, była ona bowiem pogwałceniem obowiązującego tabu, zgodnie z którym żołnierze innej rasy nie mogli podnieść ręki na białego człowieka (Fogarty 2008: 7). Ostrożni Brytyjczycy wysłali tylko dwa kontyngenty indyjskie do Europy, Francuzi natomiast bez skrupułów wykorzystywali mieszkańców kolonii jako mięso armatnie, obiecując im w zamian różne przywileje (ibid.: 11-16). W przeciwieństwie do białych żołnierzy, większość szeregowców o innym kolorze skóry była niepiśmienna, dlatego autentyczne materiały źródłowe w tym zakresie są bardzo ograniczone. Zetknięcie się odmiennych kultur, kształtowanie i kontestacja stereotypów rasowych, interakcje w strefie wojny i poza nią, żałoba po stracie bliskich w społeczeństwach kolonialnych Azji, Afryki i Ameryki Północnej, obrazy literackie wojny w nielicznych utworach pisarzy-żołnierzy innej rasy stanowią nowe, istotne tematy badawcze ostatnich lat.

Czwartą fazą rozwoju refleksji kulturoznawczej nad I wojną, której stajemy się świadkami dziś, są badania o charakterze komparatystycznym i transnarodowym. Konflikt lat 1914-1918 interpretowano dotąd przede wszystkim w kontekstach narodowych, zwracając uwagę na zjawiska i mechanizmy charakterystyczne dla danej kultury wojny. Jak zaznaczają Winter i Prost, „każdy naród ma swoją własną Wielką Wojnę” (Winter and Prost 2005: 193). Czy jest zatem możliwe przekroczyć granice interpretacji zakreślone przez historiografie konkretnych państw i narodów? Coraz bardziej istotne staje się budowanie mostów między różnymi kontekstami politycznymi, militarnymi, społecznymi oraz kulturowymi, aby wydobyć na światło dzienne podobieństwa i różnice wyjaśniające, jak ludzie $\mathrm{w}$ różnych częściach świata doświadczali wojny ${ }^{14}$. W perspektywie komparatystycznej dochodzi również powoli do zbliżenia frontu zachodniego ze wschodnim, dotąd uznawanych za oddzielne pola badawcze, co może prowadzić do pełniejszego zrozumienia dynamiki I wojny w Europie.

W stulecie I wojny światowej ważnym obszarem badań są również praktyki upamiętniania oraz postpamięci, które zmieniają się wraz z kształtem współczesnych społeczeństw. Konflikt lat 1914-1918 pozostaje nadal tematem niezwykle inspirującym w sztuce, filmie,

\footnotetext{
13 Na temat dominującej narracji o I wojnie w Kanadzie, zob. Vance 1997. Należy zaznaczyć, że w pamięci zbiorowej kanadyjskich frankofonów I wojna odgrywa nieporównanie mniejszą rolę w mitologii tożsamościowej niż dzieje się to w Kanadzie anglojęzycznej, i jawi się jako obcy konflikt wpisany w problematykę napięć między rządem federalnym a skolonizowaną społecznością potomków francuskich osadników (Biron et Parenteau 2012: 13).

14 Badania komparatystyczne często ograniczają się do kontekstu brytyjsko-francusko-niemieckiego. Oprócz przywołanych wcześniej prac E. Leeda oraz J. Wintera, warto wymienić następujące monografie: Riegel 1978; Field 1991; Stanzel and Löschnigg 1993. Przełomowym dziełem w zakresie badań transnarodowych jest trzytomowa The Cambridge History of the First World War pod red. J. Wintera.
} 
muzyce, komiksie, literaturze. Zapomniane niegdyś pola bitew stają się dziś popularną atrakcją turystyczną. Pierwsza wojna nie okazała się, jak naiwnie wierzono w 1914 roku, wojną, która miała zakończyć wszelkie inne wojny ${ }^{15}$, lecz konfliktem, który zapoczątkował stulecie licznych konfrontacji zbrojnych. W Europie Zachodniej funkcjonuje ona nadal jako punkt odniesienia, do którego porównuje się późniejsze konflikty (Ouditt 2005: 246). Upadek znaczeń i wartości, katastrofa etyczna I wojny i jej bezsens stają się bodźcem do kolejnych reinterpretacji ${ }^{16}$. Rzeź w europejskich okopach i na innych frontach, globalne potyczki i transformacje, szok artyleryjski, propaganda i cenzura, bunty szeregowców, niepokój obdżektorów - problemy te wydają się zarówno odległe, jak i nadal aktualne, a konflikt sprzed stu lat staje się źródłem istotnych metafor, oddających tożsamość i kondycję psychiczną jednostki we współczesnym świecie.

\section{Bibliografia}

Audoin-Rouzeau, Stéphane et Annette Becker 2000. 14-18, retrouver la Guerre. Paris: Gallimard (Folio).

Baratay, Éric 2017. Zwierzęta w okopach. Zapomniane historie. Tłumaczenie Barbara Brzezicka. Gdańsk: Wydawnictwo w Podwórku.

Becker, Annette 1994. La Guerre et la foi. De la mort à la mémoire, 1914-1939. Paris: Armand Colin.

- 2004. „Le sort des femmes pendant l'occupation allemande du nord de la France”. W: Evelyne Morin-Rotureau (red.). 1914-1918: Combats de femmes - Les femmes, pilier de l'effort de guerre. Paris: Autrement - Mémoires.

- 2005. „Les artistes, la guerre, le sacré”. W: Jean-Jacques Becker (red.). Histoire culturelle de la Grande Guerre. Paris: Armand Colin.

Becker, Jean-Jacques, Jay M. Winter, Gerd Krumeich, Annette Becker et Stéphane Audoin-Rouzeau 1994. Guerre et cultures 1914-1918. Paris: Armand Colin.

Bergonzi, Bernard 1965. Heroes' Twilight: A Study of the Literature of the Great War. London: Constable.

Biron, Michel et Olivier Parenteau 2012. „La Guerre dans la littérature québécoise”. Voix et Images 2 (110): 9-14.

Bourke, Joanna 1999. Dismembering the Male: Men's Bodies, Britain and the Great War. London: Reaktion Books.

Campbell, James 2005. „Interpreting the War”. W: Vincent Sherry (red.). The Cambridge Companion to the Literature of the First World War. Cambridge: Cambridge University Press.

Cannadine, David 1981. „War and Death, Grief and Mourning in Modern Britain”. W: Joachim Whaley (red.). Mirrors of Mortality: Studies in the Social History of Death. London: Europe Publications Limited.

Clark, Christopher 2017. Lunatycy. Jak Europa poszła na wojnę w roku 1914. Tłumaczenie Malwina Fiedorek, Tomasz Fiedorek. Warszawa: Wydawnictwo Akademickie Dialog.

Das, Santanu 2005. Touch and Intimacy in First World War Literature. Cambridge: Cambridge University Press.

\footnotetext{
15 The War to End All Wars - frazy tej użył angielski pisarz H. G. Wells w serii artykułów wydanych w 1914 roku przez londyńskie gazety, a następnie opublikowanych w książce The War That Will End War (Bergonzi 1965: 33$-34)$.

16 Ten zwrot etyczny obejmuje także badania konfliktu z perspektywy cierpiących zwierząt - ofiar tak wojny, jak ludzi. Zob. np. Baratay 2017.
} 
— 2013. „Introduction”. W: Santanu Das (red.). Race, Empire and First World War Writings. New York: Cambridge University Press.

Field, Frank 1991. British and French Writers of the First World War: Comparative Studies in Cultural History. Cambridge: Cambridge University Press.

Fogarty, Richard S. 2008. Race and War in France: Colonial Subjects in the French Army, 1914-1918. Baltimore: The Johns Hopkins University Press.

Fouilloux, Etienne 2005. „Première Guerre mondiale et changement religieux en France”. W: JeanJacques Becker (red.). Histoire culturelle de la Grande Guerre. Paris: Armand Colin.

Fussell, Paul 1975. The Great War and Modern Memory. New York and London: Oxford University Press.

Gilbert, Sandra 1983. „Soldier's Heart: Literary Men, Literary Women, and the Great War”. Signs 8.3: $422-450$.

Godo, Emmanuel 2016. „La guerre de 14-18: une crise de l'esprit?”. Études 6: 75-86.

Grayzel, Susan R. 1999. Women's Identities at War: Gender, Motherhood, and Politics in Britain and France during the First World War. Chapel Hill-London: The University of North Carolina Press.

Hallett, Christine E. 2014. Veiled Warriors: Allied Nurses of the First World War. Oxford: Oxford University Press.

Hynes, Samuel 1990. A War Imagined: The First World War and English Culture. London: The Bodley Head.

Leed, Eric J. 1979. No Man's Land: Combat and Identity in World War I. Cambridge: Cambridge University Press.

Lerner, Paul 2005. „Historiographie de la psychiatrie de guerre”. W: Jean-Jacques Becker (red.). Histoire culturelle de la Grande Guerre. Paris: Armand Colin.

Ouditt, Sharon 1994. Fighting Forces, Writing Women: Identity and Ideology in the First World War. London-New York: Routledge.

- 2005. „Myths, Memories, and Monuments: Reimagining the Great War”. W: Vincent Sherry (red.). The Cambridge Companion to the Literature of the First World War. Cambridge: Cambridge University Press.

Prost, Antoine 1992. In The Wake of War: "Les Anciens Combattants" and French Society 1914-1939. Thumaczenie Helen McPhail. Oxford: Berg Publishers.

Riegel, Léon 1978. Guerre et littérature. Le bouleversement des consciences dans la littérature romanesque inspirée par la Grande Guerre (littératures française, anglo-saxonne et allemande, 1910-1930). Paris: Klincksieck.

Saunders, Nicholas 2005. „Vers une archéologie anthropologique de la Première Guerre mondiale”. W: Jean-Jacques Becker (red.). Histoire culturelle de la Grande Guerre. Paris: Armand Colin. Schoentjes, Pierre 2009. Fictions de la Grande Guerre. Variations littéraires sur 14-18. Paris: Garnier.

Seal, Graham 2004. Inventing Anzac: The Digger and National Mythology. St Lucia: University of Queensland Press.

Shephard, Ben 2002. A War of Nerves. Soldiers and Psychiatrists 1914-1994. London: Pimlicoe.

Stanzel, Frank K. and Martin Löschnigg (red.) 1993. Intimate Enemies: English and German Literary Reactions to the First World War. Heidelberg: Universitatsverlag C. Winter.

Tate, Trudi 1998. Modernism, History and the First World War. Manchester-New York: Manchester University Press.

Thébaud, Françoise 1986. La femme au temps de la guerre de 14. Paris: Stock/Laurence Pernoud.

Todman, Dan 2005. The Great War: Myth and Memory. London-New York: Hambledon.

- 2008. „The First World War in Contemporary British Popular Culture”. W: Heather Jones, Jennifer O’Brien, Christopher Schmidt-Supprian (red.). Untold War: New Perspectives in First World War Studies. Leiden-Boston: Brill. 
Trevisan, Catherine 2001. Les fables du deuil. La Grande Guerre: mort et écriture. Paris: Presses Universitaires de France.

Trotter, David 2005. „The British Novel and the War”. W: Vincent Sherry (red.). The Cambridge Companion to the Literature of the First World War. Cambridge: Cambridge University Press.

Vance, Jonathan F. 1997. Death so Noble: Memory, Meaning and the First World War. Vancouver: University of British Columbia Press.

Wilson, Ross J. 2014. „It Still Goes On: Trauma and the Memory of the First World War”. W: Martin Löschnigg, Marzena Sokołowska-Paryż (red.). The Great War in Post-Memory Literature and Film. Berlin-Boston: De Gruyter.

Winter, Jay 1996. Sites of Mourning, Sites of Memory: The Great War in European Cultural History. Cambridge: Cambridge University Press.

- (red.) 2014a. The Cambridge History of the First World War. Cambridge: Cambridge University Press.

— 2014b. „Shell Shock”. W: Jay Winter (red.). The Cambridge History of the First World War. Tom 3: Civil Society. Cambridge: Cambridge University Press.

Winter, Jay and Antoine Prost 2005. The Great War in History: Debates and Controversies. Cambridge: Cambridge University Press. 